Digitalizacja archiwalnych numerów czasopisma naukowego Analecta Cracoviensia 1-24 (1969-1992) i ich publikacja w otwartym dostępie - zadanie finansowane w ramach umowy 672/P-DUN/2017 ze środków Ministra Nauki i Szkolnictwa Wyższego przeznaczonych na działalność upowszechniającą naukę

\title{
KATOLICKOŚĆ I APOSTOLSKOŚĆ KOŚCIOŁA WE WSPÓŁCZESNYM DIALOGU EKUMENICZNYM
}

Zamierzeniem niniejszej wypowiedzi jest zasygnalizowanie interesującego zabiegu hermeneutycznego dokonanego na jednym $\mathrm{z}$ podstawowych artykułów chrześcijańskiej prawdy o Kościele, w ramach ekumenicznego dialogu doktrynalnego. Prób takiego dialogu podejmuje się ostatnio na terenie chrześcijaństwa zastanawiająco dużo ${ }^{1}$. Jedną $\mathrm{z}$ nich stanowi działalność Komisji teologicznej znanej pod nazwą „Katolickość i Apostolskość" "2. Komisja ta została powołana do życia przez tzw. „mieszaną grupę roboczą" ustanowioną w r. 1965, w szczytowym okresie chrześcijańskiego entuzjazmu ekumenicznego, jakim były lata ostatniej Sesji II Soboru Watykańskiego i pięciu następnych. Mocodawcami jej był z jednej strony Kościół katolicki, a z drugiej Światowa Rada Kościołów. Co prawda, organizacja pracy tej grupy zlecona została Sekretariatowi Komisji „Wiara i Ustrój”, a z drugiej strony Sekretariatowi dla Jedności Chrześcijan, niemniej jako oficjalnie zaangażowana strona w tej doniosłej inicjatywie, także i doktrynalnej, była Swiatowa Rada Kościołów. Stanowi to szczegół interesujący przede wszystkim dlatego, że oficjalnie zaangażowani $\mathrm{w}$ niej byli przedstawiciele trzech głównych odłamów chrześcijaństwa, a więc katolicyzmu, prawosławia i protestantyzmu ( $\mathrm{z}$ anglikanizmem). I to właśnie stanowi okoliczność interesującą z punktu widzenia problematyki reinterpretacji: wzmiankowana bowiem

1 Por. N. Ehrenström, G. Gassmann, Confessions in dialogue. A Survey of Bilateral Conversations among World Confessional Families 1962-1971, Geneva 1972; H. Meyer, Luthertum und Katholizismus im Gespräch, Frankfurt a. M. 1973.

2 Por. La commission „Catholicité et Apostolicité”, "Istina”, 14 (1969) 1, 3-4; Catholicité et Apostolicité. Document d'étude de groupe mixte de travail Église catholique - Conseil oecuménique des Églises, „Documentation Catholique” 68 (1971) 1582, 273-284. Tekst Dokumentu opublikowany został na posiedzeniu Komitetu Centralnego Rady Ekumenicznej Kościołów, które miało miejsce w Addis-Abebie w dniach 10-21 stycznia $1971 \mathrm{r}$. 
„grupa mieszana”, a ściślej wyłoniona z niej Komisja doktrynalna, była terenem spotkania się trzech wielkich teologii, trzech wielkich tradycji chrześcijańskich, podejmujących po raz pierwszy braterską i dlatego jair najbardziej konstruktywną i pełną dobrej woli próbę wspólnego przemyślenia doniosłej problematyki doktrynalnej chrześcijaństwa. Stwarzało to wyjątkową zaiste szansę spojrzenia na doniosły artykuł wiary, bo spojrzenie w świetle potrójnej chrześcijańskiej optyki, co z jednej strony zabezpieczało przed zagubieniem niezmiennej treści dogmatycznej, z drugiej zaś otwierało możliwości ubogacenia teologicznego ujęcia tej treści nowymi pierwiastkami tkwiącymi w poszczególnych tradycjach chrześcijańskich.

Wracając do charakterystyki omawianej Komisji, godnym uwagi jest cel, jaki sobie ona wytyczyła. Stanowić go miało „studium podstawowych zagadnień (les problèmes fondamentaux), które regularnie pojawiają się między Kościołem katolickim a innymi kościołami” 3. Wynika więc z tego, że tak w działalności Komisji, jak i w zredagowanym przez nią dokumencie nie idzie o jakąś oficjalną ugodę między-kościelną, ale o wspólną teologiczną refleksję nad treścią wiary. Jest to więc dialog nie tyle kościołów ile teologii chrześcijańskich, nie tyle całych wspólnot ile ich naukowej refleksji nad treścią objawienia.

Na linii powyższego stwierdzenia znajduje się apel Komisji, aby rezultat jej prac jakim jest Dokument „Katolickość i Apostolskość” przekazany został kościołom, w celu uważnego przestudiowania i oczywiście zajęcia odpowiedzialnego wobec niego stanowiska. Kościoły bowiem wynikami prac Komisji nie są oficjalnie związane, a przeciwnie dopiero one powagą urzędowego, kościelnego zwierzchnictwa mogą z ewentualnych uzgodnień uczynić formułę wspólnego wyznania wiary. $\mathrm{Na}$ ten wybitnie służebny i roboczy charakter prac Komisji zwraca uwagę we wstępie wzmiankowany już Dokument „Katolickość i Apostolskość”, bę-dący szczytowym osiągnięciem Komisji: „Dokument ten, nie jest ani wspólną deklaracją, ani doktrynalną ugodą, ani czymś w rodzaju status quaestionis, ale jest jak najbardziej narzędziem pracy w służbie wspólnych poszukiwań" ${ }^{4}$.

Jeszcze raz więc widać, że walor prac Komisji i zredagowanego Dokumentu płynie przede wszystkim ze wspomnianego dialogu teologii a nie wspólnot kościelnych, w łonie których te teologie istnieją. Prowadzi to do wniosku, że choć urzędowa ranga Dokumentu którym chce-

3 „La Commission... a été constituée... "pour étudier les problèmes fondamentaux qui réapparaissent régulièrement entre l'Eglise catholique romaine et les autres Eglises»...", Catholicité et Apostolicité, Préface, nr 1, 273.

4 "Ce document d'étude, qui n'est ni une déclaration commune, ni un consensus doctrinal, ni un status quaestionis, est essentiellement un instrument de travail au service d'une recherche commune", j. w., nr 2, 273. 
my się zająć nie jest zbyt wysoka, to jednak z perspektywy problematyki reinterpretacji dogmatu jest to Dokument o dużym znaczeniu. Zawiera on bowiem zwłaszcza w części pierwszej uzgodniony przez trzy wielkie teologie, wspólny pogląd na wybrane wprawdzie, tym niemniej doniosłe artykuły wiary. Nie można tego nazwać ugodą, klasycznym zaakceptowaniem wspólnej formuły doktrynalnej, jest to bowiem tylko „,nowy opis dwu kategorii: katolickości i apostolskości”, który „zmierza do ukazania tych pierwiastków, które zaniedbane zostały w dyskusji teologicznej" 5. Ale wszystko to dokonane zostało wspólnie, przez wszystkich Dokument firmujących i dlatego ten właśnie opis jest dziełem wspólnym, wyrażającym przekonanie całej Komisji, a więc wchodzących w jej skład przedstawicieli trzech głównych wspólnot chrześcijańskich. Sensowność takiej pracy Dokument widzi w tym, że choć „zostają nadal stare rozbieżności, to jednak można je dzisiaj analizować w takim nowym świetle, które pozwala na dostrzeżenie możliwości postępu" we wzajemnym zbliżeniu ${ }^{6}$. A więc wspólna prezentacja pewnej warstwy doktryny o katolickości i apostolskości dla ukazania możliwości wzajemnego zbliżenia. Tak można by scharakteryzować pierwszą, pozytywną część Dokumentu. Druga bowiem dość poważnie różni się od pierwszej. Stanowi ona obejmujący siedem odrębnych ekskursów, zestaw bogatej i skomplikowanej problematyki teologicznej, która związana jest $\mathrm{z}$ treścią nauki o katolickości i apostolskości Kościoła ${ }^{7}$. Nie kryje się bynajmniej, że ekskursy te redagowane były przez pojedynczych uczestników Komisji i dlatego posiadają one z natury rzeczy charakter nie tylko personalny ale i wyznaniowy. Wartość więc tej drugiej części, leży nie tyle w obiektywno-realnym zbliżeniu stanowisk, ile we wspólnic prowadzonej i afirmowanej pracy, jak również we wspólnym zarejestrowaniu aktualnej problematyki związanej z obu znamionami.

Przedmiotem zainteresowania niniejszych wywodów będzie, rzecz zrozumiała, treść części pierwszej. Pomijając bowiem fakt znacznie dalej zaawansowanego zbliżenia poglądów, traktuje ona o samym rdzeniu nauki o obydwu znamionach, gdy tymczasem część druga, zajmuje siє̨ rozległym wachlarzem zagadnień pokrewnych, które mogłyby być przedmiotem osobnego studium.

\footnotetext{
5 Tamże.

6 ,Les différences anciennes demeurent, mais elles peuvent être traitées aujourd' hui sous une lumière nouvelle, qui laisse entrevoir des progrès possibles", tamże. 7 ,La seconde (partie, dop. N. S.) est composée de quelques appendices consacrés à certains aspects particuliers du problème général", tamże.
} 


\section{A. KATOLICKOSC W DAWNYM NAUCZANIU KOSCIOEA}

Z szeregu znaczeń, jakie na terenie chrześcijaństwa może mieć katolickość (katolickość w ogólności, katolickość chrześcijaństwa, katolicyzm), przedmiotem uwagi jest ten sens, który wiąże się ze szczególnym przymiotem Kościoła Chrystusowego ${ }^{8}$.

Przymiot ten stanowi jeden z najstarszych artykułów wiary chrześcijańskiej, dotyczących prawdy o Kościele. Nie wymieniany wprost i dosłownie w przekazach nowotestamentalnych, da się treściowo zupełnie łatwo wyprowadzić z Pawłowych syntez eklezjologicznych ujmujących Kościół w sensie wspólnoty ochrzczonych i wierzących, wykraczającej wyraźnie poza ograniczone przestrzennie ramy jednego zakątka, a więc mającej wyraźnie wymiar i zasięg ogólnoziemski. W swoisty sposób słuszność tego poglądu potwierdza fakt, że pozostający pod przemożnym wpływem nauki Pawłowej św. Ignacy Antiocheński, nie tylko że wątek ten wyraźnie podejmuje ${ }^{9}$, ale pierwszy w dziejach myśli chrześcijańskiej odniesie do niego nazwę, która na stałe wejdzie do podstawowej terminologii eklezjologicznej. He Katholike ekklesia, to w pojęciu Ignacego, niezawodnie realizowany Kościół Chrystusowy, tak w wymiarze lokalnej wspólnoty wierzących, jak i wspólnoty powstałej z wierzących na całej ziemi ${ }^{10}$.

Niebawem termin ten wchodzi do języka nauczania kościelnego. Naprzód pojawia się w symbolach chrzcielnych zawierających niezbędny zrąb doktryny koniecznej do zaakceptowania przez przystępujących do chrztu 11. Z kolei termin ten wkracza do urzędowych formuł oficjalnego nauczania kościelnego w jego najbardziej uroczystej formie, bo w formie nauczania soborowego. Przybiera to $\mathrm{z}$ jednej strony postać jednego z artykułów, usankcjonowanego przez Sobór, wyznania wiary: Pisteuomen eis mian katholiken kai apostoliken ekklesian ${ }^{12}$; z drugiej jednak

$8 \mathrm{Z}$ bogatej literatury ostatniego okresu na ten temat, ze względu na cenne wskazówki bibliograficzne, na uwagę zasługują: G. Thils, La notion de catholicité de l'Eglise à l'époque moderne, „Ephemerides Theologicae Lovanienses”, 13 (1936) 5-73; H. de Lubac, Catholicisme, Paris 1938; J. U. Fenton, The Catholicity of the Church, „American Ecclesiastical Review”, 117 (1947) 291-302; 375-386; 452-464 i St. Augustine's Use of the Nota of Catholicity, 118 (1948) 47-58; H. Asmussen, W. Stählin, Die Katholizität der Kirche, Stuttgart 1957; W. Beinert, Um das dritte Kirchenattribut. Die Katholizität der Kirche im Verständnis der evgl.-luth. und röm.-kath. Theologie der Gegenwart, Essen 1964; H. Küng, L'Eglise catholique, w: L'Eglise, Paris 1968, 419-448; Y. Congar, L'Eglise est catholique, w: Mysterium Salutis, t. 15, Paris 1970, 149-179.

3 Smyrn., 8, 2.

10 Por. Y. Congar, L'Eglise..., 150.

11 Por. DS. 41.

12 Por. DS. 42. 
strony używana jest w kanonach piętnujących błędne ujęcia doktryny objawionej: anathematidzei he katholike ekklesia ${ }^{13}$.

Tak poważna ranga nauki o katolickości Kościoła, rzecz zrozumiała, nie pozostała bez wpływu na naukę ojców (Klemens Alex., Euzebiusz, Orygenes, Augustyn, Cyryl Alex., Optat z Milewe), którzy w coraz to bardziej zdecydowany sposób przymiot ten przypisują Kościołowi ${ }^{14}$. Oczywiście, że zna ten przymiot i uczy o nim średniowiecze, a swoiste apogeum nauka o nim osiąga $w$ dobie potrydenckiej ${ }^{15}$. Umyślnie tak bardzo schematycznie zreferowana została sprawa występowania nauki o katolickości Kościoła w różnych okresach dziejów chrześcijaństwa, bo jest to sprawa opracowana i nie budząca poważniejszych wątpliwości. Ważniejszym jest jednak, żeby głębiej wniknąć w problem znacznie trudniejszy, jakim jest sprawa znaczenia nadawanego temu przymiotowi zwłaszcza przez chrześcijaństwo starożytne. Okazuje się bowiem, że jednomyślność terminologiczna akceptująca powszechnie i bez jakichkolwiek wahań nazwę i związaną z nią rzeczywistość, nie oznaczała bynajmniej jednoznaczności w rozumieniu treści tej rzeczywistości. Wprost przeciwnie, w pojmowaniu tej treści dadzą się wyodrębnić trzy główne warianty. Pierwszy z nich utożsamia się z pojęciem powszechności jako uniwersalizmu, obejmowania i bycia Kościoła na całej ziemi ${ }^{16}$. Przeciwstawieniem jej jest partykularyzm, polegający na ograniczeniu istnienia do jednego, ciasnego terenu. Ten rys jednak faktycznie powszechnego, uniwersalnego zasięgu Kościoła, jaki przede wszystkim narzuca cię w tym wariancie katolickości, pogłębić trzeba o jeden pierwiastek, jakim jest zdolność Kościoła żeby być dla wszystkich, wewnętrzna, strukturalna możność, żeby być do dyspozycji każdego człowieka, każdej grupy ludzkiej ${ }^{17}$. Nie trudno zauważyć, że obydwa powyższe rysy, przy całej ich odrębności wyraźnie się ze sobą wiążą na zasadzie skutku i przyczyny: Kościół de facto jest na całej ziemi, obejmuje wszystkich, bo de iure jest w posiadaniu mocy, którymi służyć może każdemu.

Sens ten nabiera pełnej wymowy, gdy zwróci się uwagę na jego historyczne, egzystencjalne uwarunkowania, związane z imponującym, że aż nieosiągalnym dla nikogo innego uniwersalizmem imperium rzymskiego, które było w stanie, do jakiegoś oczywiście stopnia przezwyciężyć nieprzeparte ciążenie ku odrębności i zróżnicowaniu tej całej mo-

13 Por. DS. 126.

14 Por. J. N. D. Kelly, „Catholique” et „apostolique” aux premiers siècles, „Istina”, 14 (1969) 1, 37-38. Rzecz godna uwagi, że brakuje tej nauki u św. Ireneusza. Por. Y. Congar, j. w., 151 .

15 Tamże, 152.

16 Por. Y. Congar, j. w., 152-3.

17 Pierwiastek ten uwypuklony został przez teologię średniowieczną. Por. J. Labrunie, Les principes de la Catholicité d'après S. Thomas, ,Revue des Sciences Philosophiques et Théologiques", 17 (1928) 633-658. 
zaiki etnicznej, kulturowej, religijnej, jaką prezentował skład ludnościowy państwa rzymskiego ${ }^{18}$. W tym kontekście łatwo zrozumieć traktowanie katolickości Kościoła jako prawdziwą wartość. Przy swoim bowiem nastawieniu wybitnie uniwersalistycznym, posiadaniu niewątpliwych walorów takie nastawienie usprawiedliwiających, a równocześnie: strzeżonej zazdrośnie i skutecznie jedności, stanowiło to uposażenie, które musiało robić wrażenie na ówczesnym środowisku. Stwierdzenie powyższe zwraca uwagę na fakt, że warunki historyczne, konkretna sytuacja życiowa, stanowiła swoistego rodzaju inspirację dla tego sposobu rozumienia katolickości. Oczywiście inspiracja ta zakładała istnienie po stronie Kościoła faktycznych możliwości, do których można się było odwołać, tym niemniej bez niej możliwości te mogły nie zostać wykorzystane. Nie trudno w tym dostrzec klasycznego elementu teologicznej reinterpretacji.

Drugim znaczeniem, które już od czasów wczesno-patrystycznych na-daje się znamieniu katolickości Kościoła, wiąże się z pojęciem prawdziwości i autentyczności. „Katolickie” więc oznaczało rzeczywiście chrześcijańskie, niezawodnie wywodzące się od Chrystusa w przeciwieństwie do tego, co nieautentyczne, heretyckie ${ }^{19}$. Katolickim mógł być np. prawowity biskup, jak i Kościół pozostający w zgodzie z całym Kościołem. Przede wszystkim jednak prawdziwym był Kościół istniejący wszędzie, a nie zacieśniony do ograniczonego terenu.

Jest rzeczą łatwo dostrzegalną, że to ostatnie ujęcie nie tylko że nie stoi $\mathrm{w}$ sprzeczności z poprzednim, ale wyraźnie i ściśle się z nim wiąże. Autentyczność bowiem Kościoła akcentowana w pierwszym ujęciu, swoje bezpośrednie źródło posiada we fakcie geograficznego i warunkującego go treściowego uniwersalizmu, jaki w Kościele zachodzi. Autentyczność Kościoła stanowi tu bezpośrednią i nieodpartą konsekwencję tak wewnętrznej, uniwersalnej mocy, jak i zewnętrznego rozprzestrzenienia Kościoła po całej ziemi. W sumie można powiedzieć, że treść katolickości Kościoła w okresie patrystycznym, obejmuje wyraźnie dwa związane ze sobą elementy, jakimi są powszechność i związana z nią autentyczność Kościoła.

Logicznym może w tym miejscu byłoby zapytać, w jakim stosunku, do tak sformulowanej doktryny patrystycznej pozostawało oficjalne nauczanie Kościoła na temat treściowej zawartości znamienia katolickości. Wydaje się jednak, że słuszniejszym będzie omówić przedtem kolejne warianty jego pojmowania. Pierwszy, wypracowany przez kontrreformację skupiał swoją uwagę na aspekcie ilościowym znamienia, upatrując jego istotę $\mathrm{w}$ szerokim geograficznie rozprzestrzenianiu się Kościoła oraz

18 Por. Y. Congar, j. W., 152-3.

19 Por. J. N. D. Kelly, art. cyt., 36-7; Y. Congar, j. w., 151. 
we względnie dużej ilości wyznawców ${ }^{20}$. Tak pojmowana katolickość Kościoła uważana była za sprawdzian prawdziwości Kościoła na tej zasadzie, że inne społeczności chrześcijańskie nie dorównują w realizacji tego wyraźnie nadanego przez Chrystusa Kościołowi przymiotu. Nie trudno zauważyć wybitnie polemicznego, apologetycznego zabarwienia tego ujęcia katolickości. Dało to asumpt teologii dwudziestego wieku do krytycznej oceny tego ujęcia i sformułowania, w nawiązaniu do znanego juz w Patrystyce, a następnie analizowanego i pogłębionego przez scho-lastykę ujęcia określanego jako katolickość jakościowa ${ }^{21}$. Istotny jej sens tkwi we fakcie, że Kościół posiada pełnię prawdy i mocy zbawczej, stwarzającej maksymalne możliwości zbawienia i rozwoju człowieka i całej ludzkości 22. Idzie więc o radykalne przesunięcie akcentu z pierwiastków zewnętrznych, wtórnych rzeczywistości tego doniosłego fragmentu prawdy o Kościele na pierwiastki wewnętrzne, podstawowe, stanowiące samo jej sedno a zarazem najgłębsze źródło.

Tak w ogólnym zarysie wyglądały sposoby pojmowania bezspornie i z całym przekonaniem przypisywanego Kościołowi znamienia.

Przechodząc do sprawy oficjalnego stanowiska Kościoła w sprawie katolickości stwierdzić trzeba, że rangę najwyższego zaangażowania nauczycielskiego posiada na pewno fakt przynależenia katolickości do Koś cioła. Powaga symboli wiary oraz wyraźne stwierdzenia soborowe, nie pozwalają na żadną w tej mierze wątpliwość. Nieco bardziej skomplikowana jest sprawa treściowej zawartości znamienia katolickości Kościoła. Nigdzie bowiem i nigdy wprost i bezpośrednio Urząd Nauczycielski nie dokonuje oficjalnego wyjaśnienia, co przez to znamię rozumie. Nie pozostaje więc nic innego, jak odwołać się do znaczenia, jakie w tym czasie było w powszechnym użyciu. Nie ulega bowiem wątpliwości, że tylko w tym znaczeniu mógł Kościół rozumieć treść katolickości, wprowadzając ją do symbolu wiary, nie dodając do tego żadnych wyjaśnień. A otóż znaczeniem obiegowym katolickości w dobie patrystycznej, było niewątpliwie znaczenie powszechności, uniwersalizmu, wykraczającego poza ciasne granice Kościoła lokalnego, partykularnego. I w tym sensie rozumienia, katolickość uważać trzeba za prawdę zdogmatyzowaną.

20 Por. Y. Congar, dz. cyt., 154; G. Thils, Les notes de l'Eglise dans l'Apologétique depuis la Réforme, Paris 1937, 222-7; H. Küng, L'Eglise, t. II, 421-3.

21 Por. G. Thils, dz. cyt., 250-253; A. de Poulpiquet, La notion de Catholicité, Paris 1920, $10 \mathrm{nn}$.

22 Por. J. N. D. Kelly, art. cyt., 39. 


\section{B. ZNAMIE KATOLICKOŚCI W DOKUMENCIE „KATOLICKOŚC I APOSTOLSKOŚC”"}

Tym, co w Dokumencie „Katolickość i Apostolskość” rzuca się w oczy przede wszystkim jest dogłębność i wszechstronność ujęcia znamienia katolickości. Perspektywa, w której ujmuje się katolickość, oświadczają autorowie Dokumentu, jest trynitarna, chrystocentryczna, pneumatologiczna, misyjna i domagająca się zaangażowania konkretnego w służbẹ ludzkości ${ }^{23}$. Wistocie, sięgając do najgłębszych źródeł katolickości jakimi są najważniejsze tajemnice chrześcijaństwa, a więc tajemnica trynitarna, chrystologiczna i pneumatyczna, Dokument kieruje zdecydowanie wzrok ku warstwie, która wprawdzie w niektórych okresach (scholastyka i czasy najnowsze) była przez teologię dostrzegana, ale nie ujmowano jej tak dogłębnie i tak wyczerpująco. Dokument zaś nie tylko, że konsekwentnie wysuwa na plan pierwszy warstwę katolickości, nie tylko wszechstronnie ją wyjaśnia, ale sięgając po jej najgłębsze przyczyny, zwraca uwagę na jej ogólno-eklezjologiczną doniosłość. Jeżeli stanowi ona swoistego rodzaju przedłużenie tamtych trzech kluczowych tajemnic, to nie da się ona już sprowadzić do niepozornego fragmentu motywacji eklozjologiczno-apologetycznej. Dokument zresztą nie ogranicza się tylko do stwierdzenia istotnych, genetycznych związków z wymienionymi tajemnicami, ale w zwięzły sposób stara się je wyjaśnić. Z tajemnicą więc Trójcy Sw. wiąże Kościół rzeczywistość wspólnoty, która sprawia, że ludzie wiążą się realnie ze wspólnotą trynitarną, stając się przez to wspólnotą zbawionych, która już z tego tytułu jest katolicka, że dokonuje się $\mathrm{w}$ niej pełnia życia, biorąca początek w życiu trynitarnym ${ }^{24}$.

Sam rdzeń jednak katolickości wiąże się ze zbawczą tajemnicą Chrystusa. Odwołajmy się do tekstu Dokumentu, który jest tu wyjątkowo wymowny: „Wysłany przez Jedynego Boga na świat, Chrystus głosił nadejście królestwa, poświęcił swoje życie za wszystkich na krzyżu i wszystkich wezwał do uczestnictwa w jego zmartwychwstaniu. Przez Niego wszystko powinno było zostać pojednane z Bogiem, ponieważ On przyniósł pokój przez krew swojego krzyża (por. Kol. 1, 20). On jest Panem 〈który otrzymał imię, które jest ponad wszelkie imię〉 (Filip. 2 , 9). On jest Tym, w którym objawia się Ojciec, Tym 〈który jest pełen łaski i prawdy (Jan. 1, 14), w którym mieszka 〈cała pełnia bóstwa〉 (Kol. 2, 9). On jest Głową, która w swoim ciele zgromadza całą ludzkość przez działanie Ducha Sw. (Efez. 1, 1-14)" 25. Chrystus więc posiada

23 ,Telle est la persepective dans laquelle nous envisageons la catholicité: trinitaire, christocentrique, pneumatique, missionaire et exigeant un engagement concret au service de l'humanité", Catholicité et Apostolicité, cz. I, nr 1, 274.

24 „L'Eglise est catholique dans son être, parce qu'elle est constituée par le don la communion trinitaire que le Verbe incarné fait à l'humanité", j. w.

${ }_{25}$,Envoyé par le Dieu unique dans le monde, il a annoncé le royaume, il 
pełnię wszelkiej doskonałości, która przeznaczona jest dla zbawienia skutecznego całej ludzkości, osiągającej w ten sposób prawdziwą swoją doskonałość, na którą posiada głębokie i wszechstronne zapotrzebowanie.

Ujęta w ten sposób tajemnica Chrytusa, a zwłaszcza wszechzbawiająca moc człowieka staje się udziałem Kościoła, czyniąc z niego posiadacza pełni środków zbawienia dla całego stworzenia, stanowiących odpowiednik zapotrzebowań zwłaszcza ludzkości $w$ zakresie zbawienia i wszechstronnego jej rozwoju. I ta właśnie moc zbawcza, tkwiąca w przechowywanej przez Kościół zbawczej tajemnicy Słowa Wcielonego, stanowi nie tyḷo jeden $\mathrm{z}$ elementów jego istoty, ale i pierwiastek znamienia katolickości, którą by można było nazwać katolickością ontyczną. Jak lapidarnie wyraża to omawiany Dokument: „Kościół przechowując na sposób ludzki i niedoskonały, tym niemniej autentyczny misterium Chrystusa, w którym wszystko zostało streszczone, jest tym samym katolicki' ${ }^{26}$.

Będąca istotnym elementem struktury Kościoła katolickość ontyczna, wiąże się ściśle z katolickością dynamiczną, polegającą na doniosłym, posiadającym wszechstronny zasięg zadaniu przekazywania i udostępniania tych nadprzyrodzonych mocy zbawczych wszystkim i wszędzie, gdzie zapotrzebowanie na te moce istnieje. Dokument formułując wyraźnie postulat „realizacji przez Kościół katolickości dzień po dniu”, szczególny nacisk kładzie na związany ze samą istotą zadania sposób jego realizacji wykluczający kierowanie się jakimikolwiek względami ludzkimi, takimi jak względy społeczne, polityczne czy narodowe ${ }^{27}$.

Dokument nie zatrzymuje się jednak na tych stwierdzeniach niewątpliwie oryginalnych, ale przecież nie obcych dotychczasowej teologii katolickości, ale próbuje wskazać na czym konkretnie polega realizacja tego posłannictwa udostępniania zbawczej mocy Chrystusa. Fragment traktujący o tym zagadnieniu ( $\mathrm{rr}$ 5) rozpoczyna się od wielce znaczącego stwierdzenia: ,Tam gdzie jest Jezus Chrystus, tam jest Kościół katolicki" ${ }^{28}$. Stwierdzenie to nawiązuje do zasady, że najgłębszym źródłem katolickości jest zbawcze misterium Wcielonego Słowa, ale równocześnie otwiera drogę do sformułowania nauki o konkretyzacji ustalonych dotąd

a donné pour tous sa vie sur la croix et les appelle tous à participer à sa résurrection. Par lui toute chose devait être réconciliée avec Dieu, car il a fait la paix par le sang de sa croix (cf Col. 1, 20). Il est le Seigneur «qui a reçu le nom qui est au-dessus de tout nom» (Ph. 2, 9). Il est Celui en qui le Père se révèle, Celui qui est "plein de grâce et de vérité» (Jn 1, 14), Celui en qui habite "toute la plénitude de la divinité (Col. 2, 9). Il est le Chef qui rassemble dans son Corps, par l'action de l'Esprit-Saint, toute l'humanité (cf Ep. 1, 1-14)", j. w.

26 ,Portant, de manière humaine et imparfaite mais néanmoins authentique, le mystère du Christ en qui toutes choses sont récapitulées, elle est dès à présent catholique", j. w., nr 3, 275.

27 Por. nr 4, 275.

28 „Là, où est Jésus - Christ, là est l'Eglise catholique” (cf. Ignace, Sm., 8, 2). 
elementów znamienia katolickości. Dokonuje się ta konkretyzacja po-przez faktycznie realizujące się życie chrześcijańskie w ramach wspólnoty kościelnej. Ta z kolei, stwarzając kontekst umożliwiający Chrystusowi zbawczą obecność w świecie, staje się rzeczywiście katolicką ,naprzód w wymiarze lokalnym". Na gruncie realnych związków jednoczących te wspólnoty ludzi zbawianych mocą tajemnicy Chrystusa, składają się te lokalne wspólnoty na ogólnokościelną wspólnotę, w której kato. lickość realizuje się par excellence ${ }^{29}$.

W ten sposób dotarliśmy do ostatniego istotnego elementu składowego doktryny o katolickości Kościoła, ustalonej zgodnie przez całe właściwie współczesne chrześcijaństwo w Dokumencie „Katolickość i Apostolskość”. W relacji powyższej pominiętych zostało kilka jeszcze innych, mniej istotnych ogniw (eschatologiczny aspekt katolickości, chrześcijańskie „grzechy” przeciwko katolickości) zawartej tam nauki o katolickości ${ }^{30}$. Celem jednak niniejszej wypowiedzi było zaprezentowanie tego, co może stanowić przykład reinterpretacji na terenie nauki o Kościele. Z powyższego punktu widzenia, przedstawiony zarys doktryny o katolickości, wydaje się być wystarczająco wymownym przykładem poprawnie przeprowadzonego zabiegu hermeneutycznego, dającym podstawę do pewnej ilości wartościowych wniosków. Pierwsze dwa mają charakter formalnometodologiczny, następne dwa charakter treściowo-merytoryczny.

$\mathrm{Na}$ uwypuklenie więc zasługuje przede wszystkim fakt, że doktryna zawarta w Dokumencie nie stanowi rezultatu procesu badawczego jednej szkoły teologicznej, działającej w oparciu o właściwą jej metodę badania. Jest raczej wynikiem stosującej swoisty pluralizm metodologiczny konfrontacji międzywyznaniowej, która do tej pory prowadziła raczej do utrwalenia się stanowisk rozbieżnych, a nie ustalania wspólnie podzielanej nauki 31. Abstrahując od wymowy ekumenicznej tego faktu, trzeba podkreślić znaczenie tego rodzaju zabiegu dla sprawy prawidłowego odczytania treściowej zawartości dogmatu chrześcijańskiego. Trzeba z całą odpowiedzialnością postawić pytanie, czy możliwa jest naukowa refleksja

29 ,Or, le Seigneur se rend présent là où dans un même lieu une communauté de croyants, marqués et engagés envers lui par le baptême, et rassemblés en son nom, écoute sa Parole et la reçoit en suivant librement l'action de son esprit, célèbre le repas eucharistique, persévère dans la confession de foi, dans l'action de grâces, dans la prière et la communion fraternelle (cf Ac. 2, 42). Grâce au Seigneur qui règne en elle, la communauté locale, réunie autour des ministres du Christ, dans la communion des saints depuis Abel le juste jusqu'au dernier des élus et donc en union avec l'Eglise de tous les temps et de tous les lieux, est une expression réelle de l'Eglise catholique. Formant une "koinonia» universelle, les communautés Iocales sont appelées à se soutenir mutuellement et à agir ensemble pour la gloire du Seigneur", j. w., nr 5, 275.

30 Mowa jest o nich w numerach 2-gim (rys eschatologiczny) i 6-tym (braki godzące w katolickość).

${ }_{31}$ Por. P. Wacker, Theologie als ekumenischer Dialog, München - Paderborn Wien $1965,1-14$. 
nad prawdą objawioną w perspektywie jednej tylko szkoły teologicznej, jednego czy jednowyznaniowego systemu teologicznego? Odpowiedź zdaje się w świetle omówionego konkretnego faktu ze znamieniem katolickości nie nastręczać żadnych wątpliwości.

Drugi wniosek tego samego formalno-metodologicznego typu pozostaje w ścisłym z poprzednim i dotyczy tego, że uzgodniona i wybitnie pogłębiona doktryna Dokumentu „Katolickość i Apostolskiość” powstała nie w wyniku typowego dla dotychczasowej teologii logicznego wnioskowania, ale na drodze braterskiego dialogu doktrynalnego, w którym trudno nie dostrzec interwencji Ducha Sw., jeżeli cały współczesny ruch ekumeniczny do Niego się właśnie odnosi. Tyle wnioski pierwszego gatunku.

W płaszczyźnie merytorycznej trzeba przede wszystkim stwierdzić, że zawarta $\mathrm{w}$ omawianym Dokumencie nauka o katolickości, stanowi zdecydowane przesunięcie jej zawartości ku pierwiastkom ontycznym i podstawowym. Stanowiło to wyraźne odejście od pierwiastków funkcjonalnych i wtórnych, na których przez długi czas bazowało ujmowanie znamion Kościoła w ogóle, a znamienia katolickości w szczególności. Ta wyraźna preponderancja pierwiastka ontycznego w stosunku do funkcjonalnego, wyraziła się nie tylko wyłącznością uwzględniania tego pierwszego pierwiastka, ale bardziej jeszcze w tym, że został on potraktowany bardziej wyczerpująco i wszechstronnie niż czyniono to dotychczas. Stanowi to niewątpliwie dobroczynny skutek wspomnianego pluralizmu metodologicznego a i w jakiejś mierze merytorycznego. Biorący udział przedstawiciele trzech wielkich odłamów chrześcijaństwa i trzech wielkich teologii wnieśli, każdy na swój sposób realny wkład w ukształtowanie takiego właśnie spojrzenia na katolickość Kościoła.

Drugi moment, który godny jest podkreślenia w wymiarze treściowym nauki Dokumentu, stanowi jej ogólnochrześcijański, swoiście ponadwyznaniowy charakter. Polega to na tym, jak się okazuje, że wizja katolickości tam zaprezentowana, da się bez trudu zmieścić, a nawet harmonizuje z systemami wierzeń wszystkich trzech głównych wspólnot chrześcijańskich, których przedstawiciele byli sygnatariuszami Dokumentu. Jest to tym bardziej godne uwagi, że to zgodne ujęcie znamienia katolickości wiąże się z tą jego warstwą, która jest na pewno warstwą donioślejszą, a nawet podstawową w jego strukturze. Ewentualne więc ro-zbieżności, związane $\mathrm{z}$ warstwami treściowo nie tak doniosłymi, muszą być również traktowane jako rozbieżności drugoplanowe.

Powyższa jednak ponadkonfesyjność ujęcia katolickości w Dokumencie, nie oznacza bynajmniej przymusu rezygnacji ze strony poszczególnych wspólnot z tych warstw znamienia katolickości, które przez długi czas na terenie tych wspólnot były wysuwane na plan pierwszy ze względu na apologetyczne korzyści, jakie dawało to tym wspólnotom. 
Idzie o katolickość ilościową, z jej dwoma elementami jakie stanowią geograficzna powszechność i wyjątkowa liczebność. Choć we wstępie do rozdziału o katolickości w Dokumencie jest wzmianka przestrzegająca przed wykorzystywaniem katolickości do przeciwstawiania sobie niektórych wspólnot chrześcijańskich, to jednak jest to zastrzeżenie, które ze względu na swoją lakoniczność i ogólnikowość, nie wyklucza włączenia do treści znamienia katolickości innych jego warstw. Jeżeli bowiem w perspektywie teologii katolickiej stanowią logiczną konsekwencję jego warstwy zasadniczej jaką jest katolickość jakościowa, ontologiczna, to teologia ta ma pełne prawo także w nich upatrywać elementy składowe intgeralnego pojęcia katolickości, mimo że pozostali partnerzy dialogu, przekonania takiego nie podzielają. Uzgodnienie bowiem w ramach dialogu jednych pierwiastków, nie zobowiązuje partnerów do rezygnacji z tych, których dotąd uzgodnić się nie dało.

\section{A. ZNAMIE APOSTOLSKOSCI W DAWNYM NAUCZANIU KOSCIOEA}

Znamię apostolskości Kościoła, stanowiło jeszcze bardziej powszechnie i bardziej zdecydowanie uznawany przez chrześcijaństwo wszystkich czasów artykuł wiary, aniżeli znamię katolickości. Legitymując się takim samym stopniem i typem zaangażowania Urzędu Nauczycielskiego, co nauka o katolickości (symbol wiary - posiadający sankcje nauczania soborowego) w świadomości zwłaszcza chrześcijaństwa pierwotnego i patrystycznego, apostolskość cieszyła się i większym prestiżem i większą, jeżeli tak można powiedzieć, notorycznością. Apostolskość stanowiła bowiem od początku jedną z najbardziej istotnych struktur chrześcijaństwa, a przekonanie o tym posiadało cechę absolutnej niemal niepodważalności ${ }^{32}$.

Ten sam jednak los co katolickość, dzieliła i apostolskość na odcinku identyfikacji jej zawartości treściowej. Choć kategoria ta była oryginalnym tworem chrześcijańskim, to jednak dokładny jej sens nie odrazu ujmowany był jednolicie ${ }^{33}$. Upłynęło dobrych parę wieków, zanim ukształtował się w świadomości wyrazisty obraz treściowej zawartości tego powszechnie i z całym zdecydowaniem przyznawanego Kościołowi przymiotu. Początkowo apostolskość nie posiadała znaczenia i wydźwięku teologicznego, lecz pokrywała się z tym, co wiązało się z Apostołami, co dotyczyło historycznych warunków, w których oni żyli. W pełni wyra-

32 Por. J. N. D. Kelly, art. cyt., 39: „....ce terme... était absolument fondamentale pour la compréhension que l'Eglise primitive avait d'elle-même".

33 Tamże. 
żał jej treść przymiotnik ,apostolski”"34. Od samego jednak początku obok wariantu neutralnego, czysto historycznego, istnieje drugi wariant znaczeniowy tego przymiotnika, religijny, dogmatyczny, kojarzący się ze sprawą nauki objawionej i dziedziny organizacji kościelnej. Podstawę tego znaczenia stanowił fakt szczególnego wybraństwa i posłannictwa, będącego udziałem Dwunastu Apostołów 35. Posłannictwo to pozostawało w ścisłym związku z przekazywaniem i kontynuacją zbawczego dzieła Chrystusa ${ }^{36}$. A ponieważ dzieło to zamknięte zostało w rzeczywistości prawdy objawionej i nadprzyrodzonej łaski, posłannictwo apostolskie przeznaczone do ich przekazywania ludziom, otrzymało swój konkretny wyraz w misji nauczycielskiej i kapłańskiej ${ }^{37}$.

W ścisłym związku z powyższym ujęciem znamienia apostolskości pozostawało inne, biorące za podstawę pochodzenie od Apostołów. To bowiem, co w zakresie doktryny czy udzielania łaski można było odnieść w niezawodny sposób do Apostołów, posiadało gwarancję autentyczności i wywodzenia się od Chrystusa a więc cechę niezawodnej prawdziwości ${ }^{38}$. W ten sposób w orbicie apostolskości znalazła się przede wszystkim sukcesja, stanowiąca konkretną gwarancję rzeczywistego wywodzenia się posłannictwa kapłańskiego od Apostołów. Gwarancją tą objęci byli przede wszystkim legitymujący się legalną sukcesją hierarchowie. Na drugim miejscu jednak dotyczyła ona także i głoszonej przez nich nauki i sprawowanej posługi zbawienia. Z sukcesją poprzez godność urzędowych następców apostolskich, powiązana była apostolskość Kościołów lokalnych, którymi następcy ci przewodniczyli. Nieprzerwana bowiem ich sukcesja sięgająca określonego Apostoła weryfikowała Kościół, w którym kiedyś odgrywali oni decydującą rolę ${ }^{39}$.

Omówione ujęcia apostolskości, nie wyczerpują pełnej jej treści 40.

34 Takie znaczenie obojętne przypisuje się niekiedy nawet św. Ignacemu Antiocheńskiemu. Por. Kelly, j. w.

${ }_{35}$ Prócz apostolatu Dwunastu występuje jeszcze szczególnie u św. Pawła apostolat pojedynczych głosicieli ewangeiii. Por. R. Schnackenburg, L'apostolicité: état de la recherche, „Istina”, 14 (1969) 1, 9. Swięty Paweł zna jednak godność apostolską, która zdecydowanie przewyższa ten apostolat zwyczajny, ze względu na szczególne powołanie przeznaczenia do ewangelizacji pogan i osobisty stosunek do Zmartwychwstałego. Godność ta w pełni przysługuje samemu Pawłowi. Por. j. w., 8. Ale ostatecznie faktem jest, że jak powie R. Schnackenburg, ,...le concept d'apôtre, non univoque dans le Nouveau Testament, rend possible différentes façons de concevoir le ministère apostolique et le principe de l'apostolicité", art. cyt., 12.

36 J. w., 15.

37 Misje te jednak nie wyczerpywały pełni tego posłannictwa, choć niewątpliwie stanowiły jego podstawowe elementy.

38 Por. Kelly, art. cyt., 41.

39 ,....Les Eglises apostoliques avaient conscience de leur continuité et que cette continuité leur paraissait garantie par les évêques qui depuis leur fondation, s'étaient succédés à leur tête". Por. Y. Congar, L'Eglise une, sainte, catholique et apostolique, w: Mysterium Salutis, t. 15, Paris 1970, 186.

40 Doniosłym np. takim pierwiastkiem jest udział Ducha Sw. w realizacji apostolskości. Por. R. Schnackenburg, art. cyt., 15-20. 
Stanowią jednak te jej pierwiastki, które zawsze w świadomości chrześcijańskiej wiązały się z tym podstawowym przymiotem Kościoła. W różnych jednak okresach, różne wyznaczano im miejsce w jego strukturze, a niekiedy różne nadawano znaczenie ${ }^{41}$. Przedmiotem szczególnego zainteresowania niniejszego artykułu jest sposób pojmowania apostolskości posiadający sankcję oficjalnej akceptacji nauczycielskiego autorytetu Kościoła. Najdobitniej akcetpacja ta wyraziła się w wyznaniu wiary przypisywanym Soborowi w Konstantynopolu (381) ${ }^{42}$. Kościół, który ma być objęty aktem wiary, jest w tym wyznaniu nazwany apostolskim ${ }^{43}$. Poza tym ujęciem doktryny o apostolskości Kościoła przez oficjalne nauczanie Kościoła wymienić trzeba drugą jeszcze wyraźną i ważną wzmiankę, a mianowicie wzmiankę z okazji formułowania anatematyzmów, mówiącą o Kościele katolickim i apostolskim jako autorze tych anatematyzmów ${ }^{44}$. Sens użytego w tym wypadku terminu, ,apostolski” pokrywa się w zasadzie ze znaczeniem, jakie posiada on w wyznaniu wiary i wyraża się w pojęciu Kościoła, legitymujcąego się przymiotem stanowiącym niezawodne kryterium jego prawdziwości, a więc wywodzeniem się Kościoła rzeczywiście od Chrystusa.

Obydwie powyższe wypowiedzi stwarzają wystarczająco mocne przesłanki, ażeby twierdzenie o apostolskim charakterze Kościoła uznać za prawdę zdogmatyzowaną, a więc definitywnie ustalającą fakt, że prawdziwy Kościół Chrystusa jest Kościołem apostolskim.

Ale tak, jak w wypadku katolickości Kościoła, powstaje pytanie co ten fakt oznaczał, jakie więc twierezeniu powyższemu przypisywano znaczenie, jaką wypełniano je treścią? Ani Sobór Konstantynopolitański, ani żaden $\mathrm{z}$ następnych wielkich soborów starożytności chrześcijańskiej zagadnienia dokładniejszego określenia treściowej zawartości apostolskości nie podjęły. Określenie takie jest więc możliwe tylko poprzez odwołanie się do będącego w dobie powstania symbolu nicejsko-konstantynopolitańskiego w powszechnym użyciu chrześcijańskiego pojmowania apostolskości Kościoła. Fakt bowiem lakoniczności sformułowania nauki o apostolskości Kościoła, upoważnia do wniosku, że pojęcie apostolskości było tak notorycznie jednoznaczne, że nie wymagało szczegółowych wyjaśnień.

41 Klasycznym przykładem i jednego i drugiego był okres Reformacji, kiedy to strona katolicka uwypuklała we własny sposób często rozumiejąc jedne (np. sukcesję) elementy apostolskości, a strona protestancka inne (np. nauka). Por. G. Thils dz. cyt., $255-256$.

${ }_{42}$ Przymiot apostolskości Kościoła nie jest wspomniany ani w symbolu apostolskim, ani w pierwszym oficjalnym soborowym wyznaniu wiary zwanym nicejskim, choć znajduje się w dekrecie soborowym dotyczącym chrztu heretyków. Por. Y. Congar, dz. cyt., $189-190$.

43 Por. DS. nr 150.

44 Por. DS. nr 43. 
A otóż istotnym elementem patrystycznego poglądu na apostolskość Kościoła, było niewątpliwie jego pochodzenie od Apostołów ${ }^{45}$ stwierdzające, że sięgał on swoimi początkami działalności Apostołów i z tą działalnością oraz szczególnym posłannictwem pozostawał w realnych związkach. Związki te $\mathrm{z}$ kolei konkretny wyraz posiadały w wywodzącej się od Apostołów doktrynie, oraz w legalnie, dzięki ostatecznemu zakotwiczeniu w posłannictwie apostolskim, posiadanym urzędzie biskupim ${ }^{46}$. W ten sposób usankcjonowana nauczaniem Kościoła nauka o apostolskości Kościoła obejmowała to, co określiła późniejsza teologia jako apostolskość pochodzenia, nauki i sukcesji - przez tę ostatnią rozumiejąc legalnie posiadaną godność kościelną.

Ujęty w ten sposób rdzeń patrystycznej doktryny o apostolskości, poddawany był w ciągu długiej historii chrześcijaństwa, wielokrotnym i różnorakim zabiegom reinterpretacyjnym ${ }^{47}$. Ostatnim $\mathrm{z}$ nich jest to, co zawiera się w Dokumencie „Katolickość i Apostolskość”.

\section{B. APOSTOLSKOŚC KOSCIOEA W DOKUMENCIE „KATOLICKOSC I APOSTOLSKOSC"}

Tak jak w wypadku katolickości, Dokument rozpoczyna swój „opis” apostolskości od wyliczenia pewnej ilości pierwiastków współczesnego przełomu teologicznego, które stwarzają podstawy dla nowego, pełniejszego spojrzenia na znamię apostolskości Kościoła. Do przesłłości należy bowiem czas, gdy apostolskość traktowana była wyłącznie jako odskocznia i teoretyczna podstawa odrębnych eklezjologii ${ }^{48}$. Nowe, wartościowe perspektywy spojrzenia na apostolskość, widzi Dokument we współczesnych badaniach na terenie chrystologii i pneumatologii, a także i eklezjologii z takimi jej fragmentami, jak pochodzenie apostolskie, powszechne powołanie misyjne, czy aspekt wspólnotowy Kościoła ${ }^{49}$. W istocie wszystkie wymienione elementy współczesnej myśli teologicznej rzucają wiele nowego światła na prawdę o apostolskości Kościoła.

Pozytywny wykład prawdy o apostolskości, rozpoczyna Dokument od tego co możnaby nazwać jej ontologią, jej bytową strukturą. Poprze-

45 Zaznaczyć trzeba lojalnie, że w pierwszej fazie ten element apostolskości odnoszono do pojedynczych Kościołów lokalnych, zawdzięczających swoje założenie określonym Apostołom i posiadających z tego względu gwarancję autentyczności w zestawieniu z niemogącymi się odwołać do pochodzenia apostolskiego kościołów heretyckich. Niemniej bardzo wcześnie, nie wiadomo dokładnie jakimi drogami znaczenie to odniesiono do Kościoła powszechnego. Por. H. Holstein, L'évolution du mot „apostolique” au cours de l'histoire de l'Eglise, w: L'Apostolat, Paris 1957, 48.

46 Por. Kelly, art. cyt., 42-43.

47 Por. Y. Congar, dz. cyt., 185-192.

48 ,...l',,apostolicité" a donné lieu à des interprétations différentes qui sont profondément inscrites dans les ecclésiologies des diverses confessions", cz. I, 274.

49 Por. j. w. 
dza go uroczyste i jednozgodne stwierdzenie ogólnochrześcijańskiego przekonania o apostolskim charakterze Kościoła, streszczającym się we fakcie obecności tajemnicy Apostołów w całej istocie i działaniu Kościoła. Powiązania te idą tak daleko, że jak stwierdza Dokument, ,w bycie i działaniu Kościoła nie ma nic coby mogło abstrahować od posłannictwa (misji) danej Apostołom raz na zawsze przez Chrystusa w Duchu Świętym, czy od dzieła którego dokonali zaszczepiając i budując Kościół w świecie" 50. Odkładając na później głębszą analizę stosunku apostolskości do Kościoła, trzeba jednak odrazu zwrócić uwagę na fakt uwypuklenia przez Dokument tego esse i agere Kościoła, w którym apostolskość posiada tak szeroki udział. Prowadzi to bowiem do wniosku, że i ona obydwa te wymiary posiada, gdyż inaczej nie mogłaby się w te dwa wymiary Kościoła angażować. W istocie współczesna myśl teologiczna coraz to mocniej podkreśla, że rzeczywistość apostolskości obejmuje dwie ściśle do siebie przylegające warstwy, dwa wzajemnie warunkujące się wymiary: ontyczny i dynamiczny ${ }^{51}$. $\mathrm{Na}$ pierwszy składa się to, czym Apostołowie byli w życiu tajemnicy Jezusa, w Jego zbawczym dziele, a więc i w założonym przez Niego Kościele. Drugi natomiast stanowi to, co w wyniku otrzymanego wybrania i powołania mieli do spełnienia i wykonania. Obydwa te wymiary ściśle się ze sobą łączą, stanowią bowiem elementy składowe jednej nadrzędnej rzeczywistości, jaką jest nadprzyrodzona tajemnica chrześcijańskiego apostolatu, tym niemniej, dla pełniejszego zrozumienia tej właśnie tajemnicy nie można nie dostrzegać ich istnienia i ich odrębności.

Dokument nie wprowadza werbalnie tego rozróżnienia, ale de facto się nim kieruje, omawiając to jeden, to drugi element.

Podstawowym pierwiastkiem ontologii apostolatu, jest historyczny fakt obecności Apostołów w życiu Jezusa jako naocznych świadków. Co prawda Dokument wyraźnie wymienia tylko apostolskie świadczenie zmartwychwstaniu 52, ale implicite, mówiąc o czynnym świadczeniu Apostołów o „obecności Pana ukrzyżowanego i tryumfującego”, sugeruje niedwuznacznie, że najgłębszą podstawę apostolatu Dwunastu stanowił obiektywny fakt osobistego ich spotkania i doświadczenia zbawczej tajemnicy Chrystusa ${ }^{53}$. Lojalnie więc trzeba stwierdzić, że temu ontologicznemu wymiarowi Dokument nie poświęca zbyt dużo uwagi. Wiąże się to niewątpliwie $z$ zasygnalizowanymi w drugiej części (Apendyks I)

50 „Il n'y a rien dans l'être et l'agir de l'Église qui puisse faire abstraction de la mission donnée une fois pour toutes aux apôtres par le Christ dans l'Esprit-Saint, ni de l'oeuvre qu'ils ont accomplie en plantant et édifiant l'Église dans le monde", $\mathrm{nr} 1,275$.

51 Por. R. Schnackenburg, art. cyt., 14-20; A. Javièrre, Sukcesja apostolska, „Concilium", 1-10 (1968) 164-171; L. Bouyer, L'Eglise de Dieu, Paris 1970, 382-399.

52 „Ceux-ci furent les témoins de la résurrection”, $\mathrm{nr} 2,275$.

53 Tamże. 
wątpliwościami odnośnie tzw. Łukaszowej i Pawłowej koncepcji apostolatu ${ }^{54}$.

Znacznie bardziej natomiast rozbudowany jest dynamiczny wymiar apostolatu. Punkt wyjścia i najgłębszą podstawę dynamicznego wymiaru apostolatu, stanowi fakt uczestnictwa Apostołów w otrzymanej od Ojca, a doprowadzonej do swego ostatecznego kresu przez Ducha Świętego, zbawczej misji Chrystusa ${ }^{55}$. Misja ta wiąże się ściśle z głoszeniem i realizacją Królestwa Bożego na ziemi, a ostatecznie zmierza do zbawienia człowieka. Obejmuje ona więc posłannictwo do głoszenia słowa Bożegu i uprawnienie do uświęcającego sprawowania zbawczej łaski Chrystusa ${ }^{56}$. Tak pojęte posłannictwo Apostołów, wywodzi się i stanowi partycypację w misji Chrystusa, Wcielonego Słowa, ale tym „który ją ujawnia, urzeczywistnia i udziela" jest Duch Sw. ${ }^{57}$. Do myśli tej o roli Ducha Swiętego w posłannictwie apostolskim, Dokument wraca jeszcze parokrotnie mówiąc o ,udzieleniu im misji przez Chrystusa w Duchu Św." (nr 1), o ciągłości posłannictwa nauczycielskiego Apostołów, będącej „dziełem Ducha Św.” (nr 3) i posłannictwie Kościoła „na wzór posłannictwa Apostołów podtrzymywanym przez Ducha Św." (nr 5 i 7). Choć bliższe określenie na czym polega to zaangażowanie Ducha Sw. w działalności Apostołów, na podstawie omawianego tekstu nie jest łatwe, to przecież fakt tego zaangażowania i poważny jego zasięg stwierdzone zostały w sposób bezsporny i dlatego bardzo wymowny, bo przecież idzie tu o stanowisko podzielane przez teologie chrześcijańskie, tak bardzo cd siebie dotychczas odległe. Jak widać, ten zastanawiający zwrot ku teclogii Ducha Sw., jaki notuje się w całym chrześcijaństwie, przeniknął także i do tego ważnego ogniwa prawdy chrześcijańskiej.

Trzecim członem tego „opisu” znamienia apostolskości jakiego dostarcza Dokument „Katolickość i Apostolskość”, jest jej wymiar eklezjologiczny. Wątek ten wyraźnie zaznacza się już od samego początku rozdziału o apostolskości. Kluczowy fragment jednak stanowi pierwszy numer rozdziału o apostolskości. Rozpoczyna go stwierdzenie o zbudowaniu Kościoła na fundamencie Apostołów. Zaraz potem jednak następuje wyjaśnie-

54 Por. 277.

55 „Envoyé du Père, Jésus-Christ a donné aux hommes le mystère du Royaume (Mc 4, 11)... Il a convoqué les hommes à son Eglise et les a chargés de continuer sa mission", $\mathrm{nr} 4,276$.

56 „Par l'annonce que les apôtres ont faite du Royaume de Dieu et par le rôle qu'ils ont joué dans l'avènement de ces temps nouveaux (Mt 10, 1-15; 19, 28; Lc 22, 30 ; Ap. 21, 14), chaque génération se rattache au rassemblement des nations et des races dans la Cité sainte. En transmettant aux hommes la promesse de cet accomplissement, bien plus en leur donnant les arrhes des biens du Royaume, les apôtres, par la puissance de l'Esprit répandu à la Pentecôte, ont suscité un vivant espoir en l'approche du renouvellement de toute chose", nr 5, 276.

57 ,Car cette mission, l'Esprit-Saint la manifeste, la réalise et la communique dans une communauté "consacrée et envoyée» comme le Christ (cf Jn 17, 18s)", nr 1, 276. 
nie, które stanowi arcydoniosłą zasadę eklezjologiczną, że „Kościół w swoim istnieniu odnosi się do osoby Apostołów, do dokonanego przez nich dzieła, tak iż jego działalność utożsamia się z ich działalnością" ${ }^{58}$. Powyższe twierdzenie zawiera przede wszystkim uznanie prawdy o głębokim i wszechstronnym powiązaniu rzeczywistości Kościoła ze znamieniem apostolskości. Apostolskość nie jest już fragmentarycznym przymiotem Kościoła, wycinkiem jego tajemnicy, ale stanowi jego wymiar powszechny, warstwę obejmującą całą jego rzeczywistość.

Dokument nie ogranicza się do tego ważnégo stwierdzenia, ale idzie dalej wskazując na mechanizm i środek tego głębokiego powiązania. Stanowi go „osoba Apostołów”, czyli jak określiliśmy wyżej pierwiastek ontologiczny apostolatu, oraz ,dzieło, którego dokonali”, w którym nie trudno odnaleźć pierwiastek dynamiczny apostolskości. Od powyższego stwierdzenia jest już tylko krok do tezy utożsamiającej działalność Kościoła z działalnością Apostołów, tezy która jest logicznym wnioskiem, ale i zasadą dyktującą z kolei nowe konsekwencje. Pierwszą z nich jest fakt „wywodzenia się" Kościoła z tajemnicy apostolatu, na którą składa się „osobowość" Apostołów oraz ich działanie, obejmujące nauczanie i udzielanie łaski. W oparciu o nie przecież, Apostołowie tworzyli nowe wspólnoty chrześcijańskie, zakładali lokalne Kościoły, budowali Kościół powszechny ${ }^{59}$. Następną konsekwencją płynącą ze wspomnianej zasady jest stałe i ścisłe powiązanie Kościoła z tajemnicą apostolatu, w wyniku rzeczywistej obecności w jego życiu istotnych jej elementów. Elementy te, dzięki działaniu Ducha Św. zapewniają ciągłość powiązania Kościoła $\mathrm{z}$ apostolatem, czynią go niezawodnie apostolskim ${ }^{60}$. W tym miejscu właściwym będzie odwołać się do ekskursu IV, mówiącego o aspekcie sakramentalnym apostolskości. Dokonuje on lapidarnego podsumowania nauki o tym, co to znaczy dla Kościoła być apostolskim. „Jesteśmy zgodni” stwierdza Dokument, że ,apostolskość Kościoła polega na wierności dla przepowiadania śmierci i zmartwychwstania Chrystusa poprzez wierną kontynuację powszechnej misji, przekazanej na początku Apostołom. Zgadzamy się więc, że apostolskość Kościoła nie obejmuje jedynie wiernego przepowiadania ewangelii, ale również i przekazywanie ,,pneumatycznej ,obecności także innymi drogami, w szczególności przez sakramenty" 61.

58 „Son existence même se réfère continuellement et nécessairement à la personne des apôtres et à l'oeuvre qu'ils ont posée une fois pour toutes et son action s'identifie avec la leur", nr 1, 275.

${ }_{59}$ „De multiples manières, par la parole et par l'action, ils ont témoigné de la présence du Seigneur crucifié et victorieux et ils ont convoqué, rassemblé et fondé les Eglises pour témoigner et préparer son avènement”, $\mathrm{nr}$ 2, 275.

"i "La continuité depuis les origines de leur témoignage et de leur action dans l'Eglise est l'oeuvre de l'Esprit-Saint et rend l'Eglise apostolique", $\mathrm{nr} 2,275$.

61 „Nous sommes tous d'accord que l'apostolicité de l'Eglise consiste dans la 
Nie ulega więc wątpliwości, że Dokument istotę apostolskości Kościoła upatruje w trwaniu i realizowaniu się w Kościele posłannictwa apostolskiego, obejmującego głoszenie ewangelii i przekazywanie sakramentalnej łaski, poprzez które udostępniana jest tajemnica i zbawcze dzieło Chrystusa ${ }^{62}$.

Ten ostatni motyw mówiący o trwaniu w Kościele i przekazywaniu poprzez posłannictwo apostolskiej tajemnicy i zbawczego dzieła Chrystusa, z jednej strony dotyka jednej z najgłębszej racji i olbrzymiej doniosłości, omawianego znamienia w strukturze Kościoła, a z drugiej stawia wobec kolejnego ważnego zagadnienia, jakim jest zagadnienie konkretnego dziedziczenia tego posłannictwa apostolskiego poprzez urząd kościelny. Dokument poświęca temu delikatnemu i skomplikowanemu zagadnieniu dwa specjalne numery ( $\mathrm{nr}$ nr 7-8), a ponadto jeden specjalny ekskurs zatytułowany: Ministère et Episcopat. W obydwu wypowiedziach mówi się otwarcie o poważnych rozbieżnościach, jakie w tej sprawie istnieją między poszczególnymi partnerami prowadzonego dialogu. Ale uwagę swoją skupia on przede wszystkim na wyłaniających się perspektywach zbliżenia w szeregu punktach tego ważnego członu prawdy chrześcijańskiej.

Punktem wyjścia wyrażonego w tej sprawie poglądu jest przekonanie, że posłannictwo apostolskie trwa i kontynuowane jest w Kościele poprzez istniejące w nim różnorakie posługi duchowe i urzędy (ministères). Chrześcijanie ,wierzą w to, że Kościół jest apostolski, ponieważ wiernie zachowuje swoją ciągłość poprzez łaskę Bożą, posłannictwo, przepowiadanie i posługiwanie które otrzymał od Apostołów" 63.

Głębokie powiązania sięgające granic tożsamości między tymi posługiwaniami a apostolatem, mają więc zdaniem Dokumentu, dwa podstawowe źródła. Stanowią je: pochodzenie od Apostołów oraz zaangażowanie Ducha Św. w ich powstawaniu i nieprzerwanym trwaniu.

Już zacytowany wyżej tekst mówi wyraźnie o wywodzeniu się posługiwania od Apostołów. Poprzedza go inny, w którym mówi się o ogólnochrześcijańskim przekonaniu, że posługiwania w Kościele sięgają samych jego początków, a więc tego okresu, który w dziejach Kościoła stał pod znakiem decydującego wpływu Apostołów na całokształt życia Koś-

fidélité à la proclamation de la mort et de la résurrection du Christ, dans la fidèle continuation de la mission universelle donné d'abord aux apôtres.

1. Nous sommes ainsi d'accord que l'apostolicité de l'Eglise n'inclut pas seulement la fidèle prédication de l'Evangile, mais également la communication de la présence "pneumatique» du Christ par d'autres voies, en particulier par les sacrements', App. IV, Conclusions et questions, 281.

E2 Por. nr 4, 276.

63 ,Mais ils croient que l'Eglise est apostolique parce qu'elle se continue fidèlement par la grâce de Dieu, la mission, la prédication et le ministère qu'elle a reçu des apôtres", j. w., nr 7, 276. 
cioła, w tym na pewno i na sprawę powstawania i rozwoju religijnego posługiwania ${ }^{64}$.

Sprawa zaangażowania Ducha Św. w pojawienie się i trwanie w Kościele różnorodnych posług religijnych, została w Dokumencie ujęta w taki sposób, że po stwierdzeniu w tych posługach rzeczywistej obecności i działania Ducha Św., zwraca się uwagę na ścisłe podobieństwo w tym względzie z zaangażowaniem Ducha Św. w posłannictwo Apostołów ${ }^{65}$. Pozwala to nie tylko dostrzec realne związki między apostolatem a posługiwaniem w Kościele, ale i uzasadnić przekonanie, że właśnie poprzez te związki kontynuacja apostolatu ma pełną gwarancję niezawodności.

Tak wyraźne i jednoznaczne powiązanie apostolskości Kościoła ze sprawą działającego w nim urzędu kościelnego, stawia nieuchronnie wobec skomplikowanego i w przyszłości bardzo spornego zagadnienia sukcesji apostolskiej. Jest bowiem oczywiste, że ta doniosła rola urzędu kościelnego, zapewniająca faktyczną realizację apostolskości, może się dokonywać tylko w urzędzie legalnie funkcjonującym na skutek niezawodnej jego więzi z posłannictwem apostolskim. Katolicyzm, więź tę upatruje z całą stanowczością właśnie w nieprzerwanej sukcesji 66. Protestantyzm nie podziela przekonania o absolutnej jej nieodzowności dla prawomocności kościelnego urzędu ${ }^{67}$. Mimo, że Dokument nie był zobowiązany do podejmowania tego trudnego zagadnienia, to przecież nie tylko o nim wspomina, ale wierny zasadzie ukazywania tego co zbliża, relacjonuje przekonanie wielu Kościołów o ,fundamentalnym znaczeniu sukcesji”, rozumianej w sensie wiernego samokontynuowania się Kościoła, ,poprzez łaskę Bożą, misję, przepowiadania i posługiwania, które otrzymał on od Apostołów” 68. Powyższe ,szersze spojrzenie”, na sukcesję, zdaniem Dokumentu posiada tę poważną zaletę, że pozwala przezwyciężyć ,zbyt prawniczo nastawione jej ujęcie”, w wyniku czego ,,zarysowują się nowe możliwości porozumienia między Kościołami" ${ }^{69}$.

Powyższe stwierdzenie Dokumentu stanowi swoistego rodzaju ukoronowanie optymistycznego bilansu teologicznej konfrontacji trzech wielkich nurtów myśli chrześcijańskiej odnośnie prawdy o apostolskości Kościoła. Optymistyczność tego bilansu ma swoje źródło przede wszystkim we fakcie, że w wyniku dialogu doktrynalnego, poważna część treści

${ }^{64}$ "C'est le rôle des ministères dans les différentes formes qu'ils (les chrétiens, dop. N. S.) ont connues depuis les origines de l'Eglise", j. w.

65 „Comme le ministère des apôtres, les ministères de l'Eglise sont donnés et soutenus par la puissance du Saint-Esprit", j. w.

66 Por. Konstytucja o Kościele (Lumen Gentium) r. III, $\mathrm{nr}$ 20; Mgr Philips, L'Eglise et son mystère au II Concile du Vatican, t. I, Paris 1967, 238-245.

67 Por. R. Schnackenburg, art. cyt., 22-28.

68 Por. Cz. II, nr 7, 276.

69 Tamże. 
znamienia katolickości rozumiana jest przez wszystkich partnerów identycznie, mimo że w jej zasięgu znalazły się tak sporne w przeszłości zagadnienia, jak miejsce apostolatu w zbawczej tajemnicy Chrystusa, rola Ducha Sw. w realizacji posłannictwa apostolskiego, miejsce i konkretne sposoby realizacji znamienia apostolskości w tajemnicy Kościoła. Chcé niewątpliwie jest jeszcze sporo punktów, które ujmuje się nie jednolicie, a nawet wręcz przeciwstawnie, to ich ilość wyraźnie się zmniejszyła i wszystko na to wskazuje, że zmniejszać się będzie nadal. I to jest drugie źródło optymizmu związanego z dokumentem „Katolickość i Apostolskość" - nadzieja, że lojalna konfrontacja teologiczna doprowadzi do zbliżenia na innych również odcinkach prawdy chrześcijańskiej, dzięki głębszemu i pełniejszemu jej zrozumieniu.

To ostatnie kieruje wzrok ku stanowiącemu kontekst niniejszego artykułu, zagadnieniu nowej interpretacji dogmatu. Pełniejsze i głębsze od dotychczasowego ujęcie znamion katolickości i apostolskości Kościoła przez omawiany Dokument, stanowi mocny dowód i wymowną ilustrację prawdy, że braterski dialog chrześcijańskich tradycji teologicznych może stanowić cenną pomoc na trudnej drodze odkrywania pełnego sensu objawionej prawdy. 